\author{
A.T. Musin \\ L.N. Gumilyov Eurasian National University, Astana \\ (E-mail:kabenov73@mail.ru)
}

\title{
Canonisation reper of complex of lines of theree-dimensional flag
}

The paper studies the three-parameter geometric image of the line - a complex of line of three-dimensional space of the flag. It identifies the main forms that depend linearly on three basic parameters differentials. The expression of the main correlations that isotropic plane passing through the beam aligns flag center beam. There was a lock, leading to full canonization frame line complex. We obtain the geometric characteristics of the structure of the canonical frame line complex. A condition in which the complex is obtained isotropic complex of lines. Write down the equations of the tangent bundle of linear systems. Obtain basic complex quadratic forms of complex. Also derivation formula obtained canonical frame set of three-dimensional space of the flag. Noted all ruled surfaces, which has a touch of the second order linear isotropic complex.

Key words: metric, space, frame, complex, derivative formula, bivector, correlation.

\section{Introduction}

Flag spaces be projective n-space, the metric is determined by the absolute, consisting of a set of nested m-planes, $\mathrm{m}=0,1, \ldots, \mathrm{n}-1$, called a flag; flag spaces denote by $F_{n}$. Taking nonistropic line as an element

$$
r=A+t e_{1},
$$

where $A$ and $e_{1}$ are vector functions of three parametric variables. Locally (1) defines the complex of lines. Including the element into frame yields empirical forms

$$
\Omega^{2}=\omega^{2}, \Omega^{3}=\omega^{3}, \Omega_{1}^{3}=\omega_{1}^{3}, \Omega_{1}^{2}=\omega_{1}^{2},
$$

that linearly depend on three differentials $d u^{1}, d u^{2}, d u^{3}$ main parametric variables. Exclusion of the latter results in the following relation

$$
\alpha \omega^{3}+\beta \omega_{1}^{2}+\gamma \omega_{1}^{3}+\chi \omega^{2}=0 .
$$

Consequently the main correlation [1] will take the following form

$$
A+t e_{1} \leftrightarrow\left(R-A,(\alpha t-\gamma) e_{2}+(\beta-\chi t) e_{3}, e_{1}\right)=0 .
$$

In this correlation of isotropic plane point that passes through the half-line (ray) is

$$
C=A+\frac{\gamma}{\alpha} e_{1},
$$

this point in [2] is called flag center of the half-line. If we shall not analyze complexes with improper (nonintrinsic) flag center, then we can write the main relation [2] in the following form

$$
\omega^{3}=\beta \omega_{1}^{2}+\gamma \omega_{1}^{3}+\chi \omega^{2} .
$$

The case of linear dependence of basic forms $\omega_{1}^{2}, \omega_{1}^{3}$, namely cylindrical complex [3] is excluded. By simple means we get the following out of (4)

$$
\delta \beta=\gamma \pi_{2}^{3}-\chi \pi^{1}, \delta \gamma=\pi^{1}, \delta \chi=-\pi_{2}^{3} .
$$

Fixation

$$
\gamma=0, \chi=0, \pi^{1}=0, \pi_{2}^{3}=0
$$


leads us to full canonization of the frame. Geometrically the equation $\gamma=0$ means the conjunction of the beginning of the frame with the flag center of the half line. Let us clarify the direction of vector $e_{2}$. Cluster of tangent linear complexes is given by the following equation

$$
\lambda p_{23}+p_{31}-\beta p_{02}=0 .
$$

Moreover, the linear complex having half-line (ray) (1) can be given in terms of

$$
\left\{a\left[A \times e_{1}\right]\right\}=0,
$$

which connects Plucker coordinates of the line (1), i.e. minors of the matrix made up of uniform coordinates of its two points: proper point $(1: 0: 0: 0)$ and improper $-(0: 1: 0: 0)$, defined by vector $e_{1}$. In order to find tangent linear complex we have to differentiate equation (8) and make a request (take it as a rule) that resulting relation will be applied towards every linear plane $\omega_{1}^{2}: \omega_{1}^{3}: \omega^{2}$. This gives us

$$
\begin{gathered}
\left\{a\left[A \times e_{1}\right]\right\}=0 ; \\
\left\{a\left[d A \times e_{1}\right]\right\}+\left\{a\left[A * d e_{1}\right]\right\}=0 .
\end{gathered}
$$

Let's take a note that basic values of external product [3] of two analytical points is

$$
\begin{array}{ll}
{\left[A \times e_{1}\right]=(1,0,0,0,0,0),} & {\left[A \times e_{2}\right]=(0,1,0,0,0,0) ;} \\
{\left[A \times e_{3}\right]=(0,0,1,0,0,0),} & {\left[e_{1} \times e_{2}\right]=(0,0,0,1,0,0) ;} \\
{\left[e_{3} \times e_{1}\right]=(0,0,0,0,1,0),} & {\left[e_{2} \times e_{3}\right]=(0,0,0,0,0,1) .}
\end{array}
$$

And if the line has Plucker coordinates

$$
\bar{p}=\left(p_{01}, p_{02}, p_{03}, p_{12}, p_{31}, p_{23}\right),
$$

then

$$
\{\bar{a}, \bar{p}\}=a_{01} p_{23}+a_{02} p_{31}+a_{03} p_{12}+a_{12} p_{03}+a_{31} p_{02}+a_{23} p_{01} .
$$

As a result of $d A=\omega^{i} e_{i}, d e_{1}=\omega_{1}^{j} e_{j},(i=1,2,3 ; j=2,3)$ and relations (10), (12), (8), (9) we obtain

$$
a_{23}=0,-\omega^{2} a_{03}+\omega^{3} a_{02}+\omega_{1}^{2} a_{31}+\omega_{1}^{3} a_{12}=0 .
$$

Here as a result of (4)

$$
\left(\beta a_{02}+a_{31}\right) \omega_{1}^{2}+\left(\gamma a_{02}+a_{12}\right) \omega_{1}^{3}+\left(\chi a_{02}-a_{03}\right) \omega^{2}=0 .
$$

because (14) has a place of all the linear planes $\omega_{1}^{2}: \omega_{1}^{3}: \omega^{2}$, is carried out identically, then

$$
a_{31}=-\beta a_{02}, a_{12}=-\gamma a_{02}, a_{03}=\chi a_{02} .
$$

Assuming $\lambda=\frac{a_{01}}{a_{02}}$, we can write the following equation $\{\bar{a}, \bar{p}\}=0$ in an expanded way

$$
\lambda p_{23}+p_{31}+\chi p_{12}-\gamma p_{03}-\beta p_{02}=0
$$

or in a canonical frame in terms of (7). Isotropic linear complex [4], i.e. complex that has absolute line can be produced when $\lambda=0$.

In reality, absolute line is a part of linear complex if and only if $a_{01}=0$, i.e. when absolute line's Plucker Coordinates $\left(0,0,0,0,0, p_{23}\right)$ satisfy the complex's equation. Flag axis [2] of the isotropic linear complex is vector $e_{2}$, as improper point defined by this vector corresponds in nil-system of improper plane. This is the end of geometrical characteristic of buildup of canonical frame. Let's take a note that linear complexes $\omega_{1}^{2}: \omega_{1}^{3}: \omega^{2}$ stangent to the linear plane are defined by equations

$$
2 \lambda=\frac{B_{2}}{B_{1}},
$$

where

$$
B_{1}=\left(\omega_{1}^{2}\right)^{2}-\omega^{2} \omega_{1}^{3}, \quad B_{2}=d \beta \omega_{1}^{2}-\omega^{1} \omega_{1}^{3}-\omega^{2} \omega_{2}^{3}
$$


are basic quadratic forms of the complex. In order to obtain equation (15) let's differentiate equation (8) one more time and add it to the latter ones. In similar manner, i.e. following the method to find cluster (7), we come to the equation (15). Out of the equation (15) it is visible that isotropic linear complex has a tangency of second order with all the linear complexes, which satisfy the equation $B_{2}=0$.

Derivative formulas of canonical frame of the complex are given by

$$
\begin{gathered}
d A=\left(\xi_{1} \omega_{1}^{2}+\eta_{1} \omega_{1}^{3}+\varsigma_{1} \omega^{2}\right) e_{1}+\omega^{2} e_{2}+\beta \omega_{1}^{2} e_{3} ; \\
d e_{1}=\omega_{1}^{2} e_{2}+\omega_{1}^{3} e_{3}, d e_{2}=\left(\xi_{2} \omega_{1}^{2}-\varsigma_{1} \omega_{1}^{3}+\varsigma_{2} \omega^{2}\right) e_{3}, d e_{3}=0 .
\end{gathered}
$$

And external differentials of basic forms can be written as

$$
D \omega_{1}^{2}=0, D \omega_{1}^{3}=\left(\varsigma_{1} \omega_{1}^{3}-\varsigma_{2} \omega^{2}\right) \wedge \omega_{1}^{2}, D \omega^{2}=\left(\eta_{1} \omega_{1}^{3}+\varsigma_{1} \omega^{2}\right) \wedge \omega_{1}^{2}
$$

Basic system of external differential equations are given by

$$
\begin{gathered}
\left(d \beta+\xi_{1} \omega_{1}^{3}-\xi_{2} \omega^{2}\right) \wedge \omega_{1}^{2}=0 ; \\
d \xi_{1} \wedge \omega_{1}^{2}+d \eta_{1} \wedge \omega_{1}^{3}+d \varsigma_{1} \wedge \omega^{2}=\left(-2 \eta_{1} \varsigma_{1} \omega_{1}^{3}+\left(\eta_{1} \varsigma_{2}-\left(\varsigma_{1}\right)^{2}\right) \omega^{2}\right) \wedge \omega_{1}^{2} ; \\
\left.\left.d \xi_{2} \wedge \omega_{1}^{2}-d \varsigma_{1} \wedge \omega_{1}^{3}+d \varsigma_{2} \wedge \omega^{2}=\left(\left(\varsigma_{1}\right)^{2}\right)-\eta_{1} \varsigma_{2}\right) \omega_{1}^{3}-2 \varsigma_{1} \varsigma_{2} \omega^{2}\right) \wedge \omega_{1}^{2} .
\end{gathered}
$$

System (18) is standard [3]. The arbitrary rule of its solution is one function of three arguments. Full system of invariants of the complex is made up of six coefficents of derivative formulas of canonical frame (16). From first equation of system (18) we can get such form through covariant derivatives

$$
d \beta=\beta_{1} \omega_{1}^{2}-\xi_{1} \omega_{1}^{3}+\xi_{2} \omega^{2} .
$$

\section{Invariants of complex of lines. Classification of complexes of lines}

Tangent plane of cylinder of the complex is parallel to bivector $\left\{\left(A+t e_{1}\right), e_{1}\right\}_{\omega_{1}^{2}=\omega_{1}^{3}=0}$, i.e. has an equation

$$
x_{3}=0
$$

and plane corresponding to the point $A+t e_{1}$ in main correlation has an equation

$$
\left(R-A, t e_{2}-\beta e_{3}, e_{1}\right)=0 .
$$

or in coordinates a following equation

$$
\frac{\beta}{t} x_{2}+x_{3}=0
$$

This is the reason why flag angle of $\varphi$ between these planes according to the known formula [5; 302], is equal to $\frac{\beta}{t}$, i.e.

$$
\beta=\varphi t
$$

This formula, which resembles Chasles' formula $[3 ; 178]$ gives us geometrical characteristic of invariant $\beta$. by the analogy with theory of the complexes of Euclid space let's call this invariant curvature.

Theorem 1. Linear plane $\omega_{1}^{2}=\omega_{1}^{3}=0$ is a cylinder with anisotropic generators.

Proof is evident from (16) when $\omega_{1}^{2}=0, \omega_{1}^{3}=0$.

Theorem 2. Invariant submanifold $\omega^{2}=\omega_{1}^{3}=0$ is a central linear plane.

Proof. Derivative formulas of canonical frame of linear plane $\omega^{2}=\omega_{1}^{3}=0$ have a following form

$$
\frac{d A}{d s}=\xi_{1} e_{1}+\beta e_{3}, \quad \frac{d e_{1}}{d s}=e_{2}, \quad \frac{d e_{2}}{d s}=\xi_{2} e_{3}, \quad \frac{d e_{3}}{d s}=0
$$

coinciding with the accuracy of labeling of invariants with derivative formulas of the canonical frame of linear plane in $F_{3}[6 ; 53]$

$$
\frac{d A}{d s}=k_{1} e_{1}+k_{2} e_{3}, \quad \frac{d e_{1}}{d s}=e_{2}, \quad \frac{d e_{2}}{d s}=k_{3} e_{3}, \quad \frac{d e_{3}}{d s}=0
$$


This means coincidence of canonical frames of coordinate based submanifold $\omega^{2}=\omega_{1}^{3}=0$ and linear complex, i.e. linear surface $\omega^{2}=\omega_{1}^{3}=0$ is central.

Theorem 3. Linear suface $\omega^{2}=\omega_{1}^{2}=0$ is a family of lines of istropical plane, enveloping curve $l$. frame

Proof. Coordinate based linear surface $\omega^{2}=\omega_{1}^{2}=0$ as it can be seen from its derivative formulas of canonical

$$
\frac{d A}{d s}=\eta_{1} e_{1}, \quad \frac{d e_{1}}{d s}=e_{3}, \quad \frac{d e_{2}}{d s}=-\varsigma_{1} e_{3}, \quad \frac{d e_{3}}{d s}=0 .
$$

Resulting from (16) is comprised of all the lines, belonging to isotropic plane and enveloping the flat curve.

Invariants $\xi_{1}, \beta, \xi_{2}$ correspond to invariants $k_{1}, k_{2}, k_{3}$ of central linear surface, $\eta_{1}$ - radius of curvature [7] of curve $l, \xi_{1}=\eta_{1} \lim \frac{\psi}{\Delta s}$, where $\psi$ is an angle between vectors $e_{2}$, corresponding to near points of curve $l, \xi_{2}$ - flag curvature of highly isotropic director of cylinder $\omega_{1}^{2}=\omega_{1}^{3}=0$. Marked geometrical characteristics of invariants of linear complex occur from analyzing its coordinated based submanifolds. Tangent plane of cylinder is defined by bivector $\left\{e_{1}, d e_{1}\right\}$, i.e. bivector

$$
\left\{e_{1}, \omega_{1}^{2} e_{2}+\omega_{1}^{3} e_{3}\right\}
$$

As known, the main cylindroid of the linear complex is a cylindroid which has its director plane coinciding with tangent plane of the cylinder. Bivector (20) is parallel to plane (19) if and only if $\omega_{1}^{3}=0$. All cylindroids passing through the given half-line (ray) are characterized by the following condition $\left(e_{1}, d e_{1}, d^{2} e_{1}\right)=0$ or $\omega_{1}^{2}\left(\omega_{1}^{2} \omega_{2}^{3}+d \omega_{1}^{3}\right)-\omega_{1}^{3} d \omega_{1}^{2}=0$. From here and from equation $\omega_{1}^{3}=0$, expressing parallellism of planes (19) and $(20)$, we obtain equation of main cylindroid of the linear complex in terms of

$$
\omega_{1}^{3}=0, \quad \omega_{2}^{3}=\xi_{2} \omega_{1}^{2}+\varsigma_{2} \omega^{2}=0 .
$$

The main correlation to the point $M=A+t e_{1}$ is related by the plane

$$
\left(R-A, t e_{2}-\beta e_{3}, e_{1}\right)=0
$$

and Chasles correlation [1] to the said point is plane

$$
\left(R-A, e_{1},\left(\omega^{2}+t \omega_{1}^{2}\right) e_{2}+\left(\omega^{3}+t \omega_{1}^{3}\right) e_{3}\right)=0 .
$$

These planes coincide when $t=\infty$ and $t=\frac{\xi_{2}}{2 \varsigma_{2}}$. Consequently, one point of tangency is improper. Second point [2] called affine center of the complex half-line, has a radius-vector

$$
A+\frac{\xi_{2}}{2 \varsigma_{2}} e_{1}
$$

Inflexional centers of half-line (ray) are defined by equation

$$
\varsigma_{2} t^{4}-2 \xi_{2} t^{3}+\left(\beta_{1}-2 \varsigma_{1} \beta\right) t^{2}+2 \xi_{1} \beta t-\eta_{1} \beta^{2}=0,
$$

where $\beta_{1}$ is covariant derivative from $\beta$, for which the following holds

$$
d \beta=\beta_{1} \omega_{1}^{2}-\xi_{1} \omega_{1}^{3}+\xi_{2} \omega^{2}
$$

Nulling one by one invariants of the complex, we obtain the following classes: 1) $\beta=0$ - special complex. i.e. array of clusters of lines in the tangent planes of the surface, described by the beginning of the frame; 2 ) $\xi_{1}=0-$ central linear surface is a highly isotropic conoid because strictional line of this linear surface is a highly isotropic line; 3) $\xi_{2}=0$ - central linear surface is a nonisotrpic cylindroid. In this case the beginning of the frame is a center of symmetry of four inflectional centers, affine center of the half-line (ray) coincides with flag center; 4) $\varsigma_{2}=0$ - cylinder of the complex degenerates into a nonisotrpical plane; one inflecional center is improper; 5) $\eta_{1}=0$ - curve $l$ degenerates into a point, beginning of frame is an inflectional center; 6$) \varsigma_{1}=0-$ tangent to a line described by flag center on a cylinder has a direction of a line of second order.

Complex of class $\beta=0$ is defined with the arbitrary rule of one function of two arguments, the remaining 5 classes of complexes are defined with the arbitrary rule of two functions of two arguments. 


\title{
References
}

1 Кованцов Н.И. Теория комплексов. - Киев: Изд-во Киевск. ун-та, 1963. - С. 292.

2 Лыжина Т.В., Мандрикова Н.А., Щербаков Р.Н. Неметрическая флаговая теория кривых и ее приложения к теории комплексов: геометрический сб. - Т. 18. - Томск: Изд-во Томск. ун-та, 1977. C. 79-92.

3 Щербаков Р.Н. Основы метода внешних форм и линейчатой дифференциальной геометрии. - Томск: Изд-во Томск. ун-та, 1973. - С. 236.

4 Лъжина Т.В. Регулюсы в трехмерном флаговом пространстве: геометрический сб. - Т. 11. Томск: Изд-во Томск. ун-та, 1973. - С. 75-91.

5 Розенфельд Б.А. Неевклидовы пространства. - М.: Наука, 1969. - С. 548.

6 Мусин А.T. К вопросу о флаговой наложимости линейчатых комплексов: геометрический сб. Т. 28. - Томск: Изд-во Томск. ун-та, 1988. - С. 53-61.

7 Власова P.К. Некоторые классы 2-параметрических семейств прямых L2 в F4 // Учен. записки / Латвийский ун-т. - 1972. - Т. 172. - С. 42-46.

\author{
А.Т. Мусин
}

\section{Үшөлшемді жалаулы кеңістігіндегі түзулер кешеннің канондық реперін салу}

\begin{abstract}
Мақала үшөлшемді жалаулы кеңістігінің түзулер кешені болып табылатын үшпараметрлік түзусызықты геометриялық кескінді оқып зерттеуге арналды. Негізгі параметрлердің дифференциалдарына сызықты тәуелді бас формалар ерекшеленіп көрсетілген. Сәуле арқылы өтетін изотропты жазықтығына сәуленің жалаулы центрін сәйкестікке қоятын бас корреляцияның өрнегі табылған. Түзусызықты комплекстің реперін толық канондандыратын беку шарттары көрсетілген. Түзусызықты кешеннің канондық репері салынуының геометриялық сипаттамасы алынған. Изотропты сызықтық комплексті кескіндейтін шарт табылған. Жанасушы сызықтық комплекстер шоғының теңдеуі айқындалған. Сондай-ақ автормен кешеннің негізгі квадраттық формалары анықталған, сол сияқты үшөлшемді жалаулы кеңістігіндегі түзусызықты комплекстің канондық реперінің деривациялық формулалары алынған. Изотропты комплекспен екінші ретті жанасуда болатын барлық түзусызықты беттер белгіленген.
\end{abstract}

\author{
А.Т. Мусин
}

\section{Канонизация репера комплекса прямых трехмерного флагового пространства}

\footnotetext{
Статья посвящена изучению трехпараметрического линейчатого геометрического образа - комплекса прямых трехмерного флагового пространства. Выделены главные формы, зависящие линейно от трех дифференциалов основных параметров. Получено выражение главной корреляции, которая изотропна плоскости, проходящей через луч, и приводит в соответствие флаговый центр луча. Отмечена фиксация, приводящая к полной канонизации репера линейчатого комплекса. Получена геометрическая характеристика строения канонического репера линейчатого комплекса. Найдено условие, при котором получается изотропный комплекс прямых. Выписано уравнение пучка касательных линейных комплексов. Получены основные квадратичные формы комплекса. Также получены деривационные формулы канонического репера комплекса прямых трехмерного флагового пространства. Отмечены все линейчатые поверхности, с которыми соприкасается изотропный линейный комплекс второго порядка.
} 


\section{References}

1 Kovantsov N. I. Theory of complexes, Kiev: Publ. House Kiev University, 1963, p. 292.

2 Lyzhina T.V., Mandrikova N.A., Shcherbakov R.N. Geometrical collection, Tomsk: Publ. House Tomsk. University, 1977, 18, p. 79-92.

3 Shcherbakov R. N. Bases of a method of external forms and line differential geometry, Tomsk: Publ. House Tomsk. University, 1973, p. 236.

4 Lyzhina T.V. Geometrical collection, Tomsk: Publ. House Tomsk. University, 1973, 11, p. 75-91.

5 Rosenfeld B.A. Non-Euclidean spaces, Moscow: Nauka, 1969, p. 548.

6 Musin A.T. Geometrical collection, Tomsk: Publ. House Tomsk. University, 1988, 28, p. 53-61.

7 Vlasova R.K. Scientists. rec. Latvian University, 1972, 172, p. 42-46. 